\title{
REVISITING THE MAINSTREAM: THE MEANING OF WORK FOR PEOPLE WITH ACQUIRED DISABILITIES
}

\author{
MARIANA F. G. GALVÃO ${ }^{1}$ \\ (iD) https://orcid.org/0000-0001-9226-3630 \\ ANA HELOISA DA C. LEMOS² \\ (iD) https://orcid.org/0000-0001-6222-6628 \\ FLÁVIA DE S. C. N. CAVAZOTTE ${ }^{3}$ \\ (iD) https://orcid.org/0000-0002-5450-3573
}

To cite this paper: Galvão, M. F. G., Lemos, A. H., \& Cavazotte, F. S. C. N. (2019). Revisiting the mainstream: The meaning of work for people with acquired disabilities. Revista de Administração Mackenzie, 19(spe). doi:10.1590/1678-6971/eRAMD180079

Submission: Apr. 30, 2018. Acceptance: Aug. 08, 2018.

1 Fundo Brasileiro pela Biodiversidade (FUNBIO), Rio de Janeiro, RJ, Brazil.

2 Pontifícia Universidade Católica do Rio de Janeiro (PUC-Rio), Rio de Janeiro, RJ, Brazil.

\footnotetext{
(c)) BY 


\section{ABSTRACT}

Purpose: The study aimed to investigate the meanings attributed to work by people with acquired disabilities.

Originality/value: The study unveils a new understanding of the meaning of work for people with acquired disabilities.

Design/methodology/approach: There were conducted in-depth interviews with ten people with acquired disabilities and inserted in the labor market.

Findings: The results of this analysis suggest that, for the interviewed group, the work shares its importance with other spheres of life, like the affective one and the family circle. Among the meanings discussed in the scholarly literature, such as pleasure in working and the work as a form of social interaction, there were also new specific meanings attributed by the group, related to the identity of the person with disability, like barriers overcoming, the combat against the stigma of incapacity and the positive impact generation. On the other hand, remuneration and career progression appear as a consequence of work, rather than a factor that brought meaning to their work activities. The findings of this study contributed to a better understanding of the different meanings attributed to work by people with an acquired disability. Among that, the results pointed to the existence of other meanings than the usually addressed in the scholarly literature of the theme, what reinforces the contribution of this article to the study of the meaning of work.

\section{KEYWORDS}

Meaning of work. People with disabilities. Inclusion. Diversity. Job Market. 


\section{INTRODUCTION}

Work is a vital life dimension, as it occupies substantial amounts of one's time and for its symbolic value (Hackman \& Oldhan, 1976; MOW, 1987; Morin, 2001; Tolfo \& Piccinini, 2007; Rosso, Dekas, \& Wrzesniewski, 2010). We spend most of our time in the work environment, and we think about it even when we are not fiscally at work. Many studies on the subject indicate that most people would work even if they did not need salaries to survive (MOW, 1987; Morin, 2001; Morse \& Weiss, 1955), which suggests that, besides compensation, people find other meanings in working. In the field of study on work and subjectivity, researchers have been attempting to understand on a more specific level how psychosocial processes influence the meaning of work for different groups.

National publications on the subject have focused, majorly, on understanding the meaning of work for women, youth, and workers in specific career areas (Spinelli-De-Sá \& Lemos, 2017). Among studies on people with disabilities and work, both in management (Lima, Tavares, Brito, \& Cappelle, 2013) and psychology (Coelho, Sampaio, \& Mancini, 2014; Paiva, Bendassolli, \& Torres, 2015; Assunção, Carvalho-Freitas, \& Oliveira, 2015; Santos \& Carvalho-Freitas, 2018), few are focused on understanding the various meanings associated to work by people with disabilities, with the exception of recent publications by Lima et al. (2013), as well as Santos and Carvalho-Freitas (2018).

Internationally, research on people with disabilities and their work has focused on groups who share one type of disability, or have the same origin for their disabilities, for example, the value of work for people with spinal cord injuries (Ullah, Fossey, \& Stuckey, 2017; Leiulfsrud, Ruoranen, Ostermann, \& Reinhardt, 2016, Ruoranen, Post, Juvalta, \& Reinhardt, 2015), or cerebral injuries (Johansson \& Tham, 2006). The literature also covers the intersections between disability and minority groups, such as Randolph's (2005) who studied women with disabilities.

People with disabilities make up a significant part of the Brazilian population - according to the IBGE Census (2010), approximately 45 million people ( $24 \%$ of the population). Despite making up a significant percentage, this group is a minority, as it constitutes a vulnerable, marginalized part of society (Moreno, 2009), whose access to work involves many barriers (Sassaki, 2009). More than half of people with disabilities, of working age (54\%), were not part of the job market in 2010 (IBGE, 2010). However, the number 159 convention, on professional rehabilitation and People with 
Disabilities' Jobs from the International Labour Organization (Brasil, 1991a) established that their signatories, among them, Brazil, should make changes to achieve effectively equal opportunities and treatment among workers with disabilities and other workers. Thus, because of the $\mathrm{n}^{\circ}$ 8.112/1990 (Brasil, 1990) law, people with disabilities were given the right to quotas in public tenders, and, subsequently, the $\mathrm{n}^{\circ} 8.213 / 1991$ law was institutionalized for the private sector as well, with a mandatory position percentage, punishable by fine otherwise (Brasil, 1991b). Inspection of these laws and the inclusion of workers with disabilities has intensified over the last five years - according to data from the Ministry of Labour, there was a $20 \%$ increase of formally employed people with disabilities in this period. In 2015, 403, 3 thousand people with disabilities had a formal job (MTE, 2015).

The importance of work for identity construction, and the specificities and obstacles still faced by people with disabilities when attempting to enter the job market, have motivated us to research this subject, with the intention to investigate the meaning of work for people with acquired disabilities. The higher demand for the inclusion of people with disabilities in organizations, in current days, reinforces our interest in this particular group and points to the necessity of widening our understanding of these people's feelings towards work. The decision to study those with acquired disabilities, as opposed to those with congenital disabilities, owed itself to the supposition that the acquisition of disabilities may affect the formation of those people's perceptions of meanings and their very social standing. These individuals have the option of retiring after acquiring their disability (Brasil, 1991a) and, perhaps, for this reason, they have received little attention. Thus, it is an example of a group in need of further research (Santos \& Carvalho-Freitas, 2018).

Since the meanings attributed to work do not only vary between individuals but may also change for the same person over time (Ashforth, 2000), the convergence between the issues related to people with acquired disabilities and the roles of work for an individual presents an opportunity to better understand changes in one's view of the meaning of work. The participants of this study have acquired their disabilities during their teenage or adult years - when identity formation has already reached a point of maturity or is close - and when altering his/her physical/sensorial reality calls for a reassessment of one's entire social existence, including in the work environment.

Individuals with acquired disabilities are, contemporarily, part of a group considered disadvantaged, but this has not always been the case. 
These individuals may face more severe challenges relating to their self-concepts, particularly towards their identity and feelings of self-efficacy, than people with congenital disabilities, with consequences for their well-being (Bogart, 2014). In this way, another contribution of this study is further understanding these people's meanings of work, and how they affect their identity construction. One of the few studies that focus specifically on the meaning of work for people with acquired disabilities, from psychology (Santos \& Carvalho-Freitas, 2018) highlights the necessity to understand this issue better. Thus, the present research contributes towards more in-depth knowledge on the subject, as it focus on individuals with acquired disabilities of varying educational degrees when compared to other study subjects, and as it presents meaning categories originated from field studies on work and subjectivity.

\section{THEORETICAL REFERENCE}

\subsection{The Meaning of Work}

In the field of research on work relations and organizations, many authors have investigated the meaning of work, its antecedents and consequences for people and for social dynamics (Morse \& Weiss, 1955; Hackman \& Oldhan, 1976; MOW, 1987; Brief \& Nord, 1990; Rosso et al., 2010). This attribution, or formation of meaning, finds itself in the subjective sphere and involves not only individuals but also social and cultural factors (Rodrigues, Barichello \& Morin, 2016).

Although the terms "meaning" and "significance" are commonly used interchangeably (Tolfo \& Piccinini, 2007), there are notable differences, especially relating these terms to the meaning of work. Finding meaning in occurrences comes from social interactions and deals with the process of producing meanings and the significance they carry, i.e., the subject's significance of a signal (Tolfo, Coutinho, Almeida, Baasch, \& Cugnier, 2005). The significance of a word corresponds to a symbol, while its meaning is unending, as it varies according to context, leading to a change in the way which people interpret aspects of their lives and experiences.

This way, one's personal, subjective meaning relating to a specific significance depends on his/her appropriation, as well as the degree and manner with which one appropriates it according to their personal history (Basso, 1998). The construction of meanings relating to work occurs through 
socialization, where the individual appropriates and recombines the social and material elements of reality, just as his/her work conceptions - originated from the many forms of knowledge from the person's historical background (Tolfo et al., 2005). The difference between significance and meaning is also subject in Bendassolli and Gondin's (2014) study, who further the discussion bringing contributions from phenomenology and general sociology, as well as by incorporating the concept of the psychological role of work in the discussion, to rethink the articulations between significance and meaning regarding work. Despite these differences, in our study meaning and significance will be used interchangeably, a common practice in studies on this subject (Tolfo \& Piccinini, 2007).

Studies on the meaning of work began sometime in the mid-fifties (Morse \& Weiss, 1955), gaining more ground with the creation of the MOW workgroup (1987). The MOW group (1987) defines work a paid job - even if it is self-employed work, because of the movement towards institutionalization, which involves a set of rules, structures, and organization to which we abide in work relations. On the other hand, Morin (2001, p. 16) defines work as a "productive activity that gives something value", which adds the notion of efficiency to the construction of meaning to the studies on labor, i.e., work that is well executed generates a positive transformation.

The time one spends at work is one of the factors that led to studies on the subject. When the MOW group published its study, scholars believed that in industrial societies this amount of time reached one-third of the time an individual is awake. This time is increasingly harder to account for, since the work sphere is not itself closed, but interposes the others life dimensions (family, leisure, etc.) and the temporal and spatial frontiers that once separated work from personal life have become increasingly fluid due to the use of new technologies (Cavazotte, Lemos, \& Brollo, 2014).

The relationship between the work sphere and other spheres of life is one of the points brought up when scholars discuss the centrality of work, defined as "the general belief in the importance of work for one's life" (MOW, 1987, p. 17). This centrality possesses two theoretical components: belief/value, through the role carried by work in the individual's life, and the decision-making process, that is, the preference for labor activity vis-a-vis other spheres of life (MOW, 1987).

Regarding the belief/value component, the MOW group (1987) discusses two properties: identification and commitment/involvement with work. Identification is a consequence of the cognitive process, based on the comparison between work as an activity and the perception of his/herself. 
Commitment, for once, is the affective answer to the recognition of labor as a part of life, and the involvement may include behavioral components, such as time spent on labor activities.

The decision-making component refers to the premise that people have segmented experiences in each sphere of life, and that some are preferred over others. The favorites are those to which people attribute most value, the ones with the most meaning, and that generate the most involvement and commitment. Work is one of such spheres, able to occupy a central spot when it is the favorite, a contiguous or shared spot when other spheres also have great importance or a peripheral sphere when it is the least important (MOW, 1987).

Based on the MOW group's research traditions, Wrzesniewski, McCauley, Rozin, and Schwartz (1997) discussed work motivations, which can be categorized as intrinsic or extrinsic in origin. While intrinsic motivation may be related to callings, pleasure, and challenges, extrinsic motivation would be associated with career and the work activity itself. Callings are not necessarily linked to the faith calling but present themselves as a form of giving meaning to one's life (Rosso et al., 2010). Despite intrinsic motivation coming primarily from individual subjectivity and extrinsic motivation being related to the environment and external factors, they are not mutually exclusive - callings, for example, may not be pleasing at all times and careers may present numerous challenges (Wrzesniewski et al., 1997).

Morin's (2001) studies showed that autonomy (freedom in decision making and a sense of responsibility) and feedback (the concept itself) are factors generated by interest in work. Similarly, the MOW group (1987) believes that with more autonomy and learning opportunities, more chance of work commitment which, for once, is associated with centrality in an individual's life. The salary is what allows the worker to deal with most of his necessities, without depending on others, allowing for a feeling of security and independence (Morin, 2001; Morin, Tonelli \& Vieira, 2007).

According to Morin (2001), the pleasure and the feeling of realization obtained from executing tasks give meaning to work and, according to the author, this is when individuals express their talents and skills. These motivations, which reach beyond remuneration, are the main factors which lead to most people's affirmations that they would still work despite not needing the money to sustain themselves for the rest of their lives. The main reasons for this choice were the most diverse: social insertion and interactions, feeling of belonging, occupying one's self, avoiding boredom, on top of giving meaning to one's life (Morse \& Weiss, 1955). 


\subsection{Work and Social Insertion}

The importance of work in an individual's life discussed by sociology (Dubar, 2005; Durkheim, 1977; Offe, 1989; Castel, 1998). To Dubar (2005), recognition at work established professional relationships, and personal dedication is part of identity construction, with labor impediment being an intimate form of suffering, a blow against one's identity generating social turbulence.

Castel, for once, (1998, p. 24) defines work as "privileged facilitation for inscription into the social structure". The author works with the concept of "social cohesion zones" in which stable employment is an integration factor, while not being a part of the job market or any productive activity, becomes a factor for isolation or dissociation. In between both situations, stable work, and unemployment, there is a zone of social vulnerability, in which there is work, but established under poor conditions.

Castel (1998) treats these zones as transitory, in other words, the same person, throughout his/her life, may flow across them, and this is common. This mobility leads the author to opt for the term "disaffiliation" instead of isolation-considered by him irreversible. Upon discussing the contemporary "social issue," Castel (1998) highlights the maintenance of social cohesion and order, and that work plays the central role in this maintenance. To the author, insertion into the social order is associated with the ability to work, and this factor conditions the treatment of different populations. Based on this distinction of treatment, people with disabilities would be classified, in primary sociability, as being within the theory of disadvantage. Despite being different in their disabilities, the author believes that they have in common the inability to provide for their necessities, being incapable of working. These incapacities, for one, renders them free from having to work (Castel, 1998).

The "disadvantaged" population, according to Castel (1998), does not affect social cohesion, because, since they are considered incapable, their removal from the workforce is natural, which legitimizes their need for support. Those that are considered as "at a disadvantage," receive different treatment than those who do not work, but have working "conditions"; the members of the second group are stigmatized as "tramps" and are considered a threat to social cohesion. According to the author, there is a risk of disaffiliation when the group of close relationships kept by the person, which is also his/her familiar/social inscription, is not enough to provide for their security and basic needs. 
While in sociology work is associated with social insertion, for labor psychodynamics, what is essential to work is not visible, but part of intersubjective processes is mobilized by its execution (Dejours, 2004). When discussing symbolic satisfaction, Dejours (2004) highlights the central role of giving meaning to work in a person's relationship with their desires in that dimension of life. Through the way of work relationships social validation occurs, which involves social recognition mechanisms of a person's utility and abilities. For Dejours (2004), these mechanisms serve a fundamental role in identity registration, of what makes one unique, participating in the person's identity construction. In line with the author's premises, this study sees the disabled worker's life experiences as central to the health-work relationship and assumes that these life experiences are oriented by this person's for his/her aspirations and the affirmation of their new identity.

\subsection{The inclusion of people with disabilities in the job market}

Regarding their social inscription, people with disabilities have conquered ground in the job market - even if not as much as when compared to people without disabilities. Their inscription in the world of work is directly related to the process of insertion into society as a whole.

To describe the long process of incorporation of people with disabilities in the job market, literature dedicated explicitly to the subject uses different terms to portray the steps in this journey. Sassaki (2010) identifies four historical phases referring to the participation of a disabled person in the job market. The first is exclusion, associated with the historical moment when it was considered cruelty if disabled people had to work, a paternalist idea that denied these people's capacity. The second is segregation, where disabled people were put into institutions and worked there with low income and no employment relationship, the paternalist mindset still present. The third is integration, where there is an employment relationship, but there is no adaptation in companies, except small tweaks in work posts and, frequently, specific positions created for people with disabilities. The term insertion is also used to describe this movement of bringing the disabled person into the productive sphere of society, although depending on their efforts (Barnes \& Mercer, 2005). The inclusion would be, then, the final phase by Sassaki (2010), in which the world of work the necessity of adapting from both ends - the disabled persons and the companies - which must be prepared for a new relationship of coexistence. Inclusion is, therefore, a 
process in which both sides depend on efforts for disabled people to be proper citizens, not being limited to specific situations.

In understanding these distinctions, especially regarding the political battles fought by disabled people, in the present study we opt to utilize, preferably, the term inclusion when referring to the process of incorporating these individuals into the world of work. We do this, despite understanding that sociology (Durkheim, 1977) does not make an important distinction between the terms inclusion and insertion while giving preference to the latter to refer to both, the inscription of individuals to the world of work and their belonging to contemporary society. The term insertion was used, in this article, only to refer to social inclusion.

In Brazil, academic production in Administration on the inclusion of disabled people in the job market tends to take on the subject while focusing on people management processes, mostly, and while not deepening aspects that deal with disabled people as the subject. Among the objects of study are: the interface between inclusion of disabled people and human resource practices (Maccali, Kuabara, Takahashi, Roglio, \& Boehs, 2015); the process of inclusion while focusing on training and development practices (Maia \& Carvalho-Freitas, 2015); and the organizations' cultural reactions to the professional inclusion of disabled people in the work environment (Sá, Oliveira, Dias \& Barbosa, 2017). The research focused on disabled people's perspective tends to originate in the field of Psychology or Sociology.

In one of the few studies in the administrative field on the meaning of work for disabled people, Lima et al. (2013) postulate that studying these people's meanings of work is essential. That is because, more than a source of income, work represents an escape from social isolation and stigmas, a form of achieving independence, not just a source of forming social bonds (Lima et al., 2013). This study busts the myth of unproductivity and incapacity - the interviewees insist that they feel useful when they work, by assuming responsibility for newfound duties. Their interaction with others was also noted as an element attributing meaning to work: "Social integration brings feelings of equality which help in breaking the social stereotype that labels people as deficient and incapable" (Lima et al., 2013, p.58). However, despite the previously mentioned positive aspects of the meaning of work, the interviewees also reported feeling stereotyped and facing prejudice, both from their own families, as from their colleagues. Besides pity, apprehension, and overprotection, some of them reported cases of them being presented jobs seen as "less noble," or beneath their capabilities, which generates demotivation. 
This kind of "meaningless" activity also appears in Paiva et al. (2015) article, in which interviewees report that their colleagues would refrain from giving them their instructions for their assignments, and would ignore their input, undervaluing their capacity to produce and contribute to the organization. Furthermore, they observed that development policies for disabled people are not clear, despite directly affecting their job satisfaction.

Despite the precariousness of the work offered to the disabled person, in Coelho et al. (2014) study, interviewees showed job satisfaction because, according to them, work organizes one's daily life, allows relationships, and is an important component of their identities. Work as a source of pleasure also appears in studies as a consequence of feeling useful, creating social relationships and strong emotional bonds.

Regarding studies directly focused on people with acquired disabilities, Santos \& Carvalho-Freitas' (2018) study presents, as the main feelings associated by the interviewees to work, the following aspects, ranked by order of relevance: 1 . Distraction, occupation and the realization of activities; 2. Independence and survival; 3. Pleasure and satisfaction; 4. Life filling; 5. Utility; 6. Attribution of personal value. The authors discuss each of these aspects in the article, adding essential contributions to understanding the subject.

It is worth noting that after revising the recent literature, convergence of work and disabilities configures a new research field, especially, in administration. Our interest in this field is to further the understanding of the meaning of work for people with acquired disabilities. Why do people with disabilities opt to work even if acquiring a disability would allow them to retire? What are the meanings of work for such a person? Did the acquisition of their disability affect their meaning of work? What is the role of work and the meanings attributed to it during the disabled person's identity construction? The search for such knowledge has guided this empirical study.

\section{METHODOLOGICAL ASPECTS}

To understand the meanings associated to work by people with acquired disabilities, we interviewed, between October and December of 2016, in the city of Rio de Janeiro/RJ, ten individuals from different job market sectors (formal or informal), aged between 31 and 68 years. This number resulted from the process conceptually known as theoretical saturation, reached 
when reports start to become repetitive, without new meanings added to the analysis (Glaser \& Strauss, 2006). It is common for this saturation to manifest itself around the tenth interview, when it is already possible to visualize a common answer repertoire, despite personal variations. In the current study, this repertoire was evident by the eighth interview. Therefore we felt it adequate to interview other two subjects, intended on confirming such a perception.

We accessed them through contacts with institutions renowned on the subject of inclusion, specialists on the subject and utilization of the Snowball method, in which an interviewee refers us to another with the desired profile. The interviews were guided by a semi-structured interview guide, with 26 questions separated into the following blocks: 1. Life trajectory; 2. Profession; 3. Current job; 4. The importance and meaning of work; 5. Labor outside the work environment; and 6. Professional identity. The interviews were done in person (in the work environments, public locations, or the interviewee's home), by Skype or telephone according to the interviewee's convenience, and last close to one hour. All interviews were recorded, with subject authorization, and later transcribed. Figure 3.1 synthesizes the interviewees' profiles.

Transcription analysis was done to identify the central themes, highlighted by the interviewees, which promotes the construction of meaning associated with work. Based on the reports we were able to map the thematic repetitions, which allowed the creation of analytical categories. The next section is organized based on the categories observed in the analyses, where we discuss the results of the interviews (Boeije, 2010).

(Figure 3.1)

INTERVIEES' PROFILES

\begin{tabular}{ccccccc}
\hline Ref. Gender & Age & Disability & $\begin{array}{c}\text { Origin of } \\
\text { Disability }\end{array}$ & $\begin{array}{c}\text { Age of } \\
\text { acquisition }\end{array}$ & $\begin{array}{c}\text { Current } \\
\text { profession }\end{array}$ \\
\hline E1 & Female & 56 & Quadriplegia & Car accident & 23 Years & $\begin{array}{l}\text { President of an } \\
\text { organization focused } \\
\text { on inclusion and } \\
\text { dancer }\end{array}$ \\
\hline E2 & Male & 41 & Paraplegia & Hit by car & 18 Years & $\begin{array}{l}\text { Kite maker and } \\
\text { salesman }\end{array}$ \\
\hline E3 & Male & 52 & $\begin{array}{l}\text { Complete } \\
\text { Blindness }\end{array}$ & $\begin{array}{l}\text { Retinitis } \\
\text { pigmentosa }\end{array}$ & $\begin{array}{l}\text { Complete Blindness } \\
\text { at 23 years of age }\end{array}$ & $\begin{array}{l}\text { Musician (flute and } \\
\text { saxophone) }\end{array}$ \\
\hline
\end{tabular}




\section{(Figure 3.1 (conclusion))}

INTERVIEES' PROFILES

\begin{tabular}{|c|c|c|c|c|c|c|}
\hline Ref. & Gender & Age & Disability & $\begin{array}{l}\text { Origin of } \\
\text { Disability }\end{array}$ & $\begin{array}{c}\text { Age of } \\
\text { acquisition }\end{array}$ & $\begin{array}{c}\text { Current } \\
\text { profession }\end{array}$ \\
\hline E4 & Male & 42 & Paraplegia & Shot & 18 Years & $\begin{array}{l}\text { Professor at an } \\
\text { evangelical church }\end{array}$ \\
\hline E5 & Female & 38 & $\begin{array}{l}\text { Complete } \\
\text { Blindness }\end{array}$ & $\begin{array}{l}\text { Stargardt } \\
\text { disease }\end{array}$ & $\begin{array}{l}\text { Complete Blindness } \\
\text { at } 23 \text { years of age }\end{array}$ & $\begin{array}{l}\text { Actress, screenwriter, } \\
\text { and dancer }\end{array}$ \\
\hline E6 & Male & 58 & Paraplegia & Car accident & 32 Years & $\begin{array}{l}\text { Lawyer and president } \\
\text { of the disabled person } \\
\text { rights Commission }\end{array}$ \\
\hline E7 & Female & 31 & $\begin{array}{l}\text { Monocular } \\
\text { vision }\end{array}$ & $\begin{array}{l}\text { Marfan } \\
\text { syndrome }\end{array}$ & 21 Years & $\begin{array}{l}\text { Administrative } \\
\text { assistant }\end{array}$ \\
\hline E8 & Male & 63 & $\begin{array}{l}\text { Reduced } \\
\text { mobility }\end{array}$ & Disease & 17 Years & Bank architect \\
\hline E9 & Female & 46 & $\begin{array}{l}\text { Leg } \\
\text { amputee } \\
\text { (both) }\end{array}$ & Hit by car & 19 Years & $\begin{array}{l}\text { University professor } \\
\text { and physiotherapist }\end{array}$ \\
\hline E10 & Female & 68 & Leg amputee & $\begin{array}{l}\text { Motorcycle } \\
\text { accident }\end{array}$ & 45 Years & $\begin{array}{l}\text { Doctor (ginechology } \\
\text { and obstetrics) }\end{array}$ \\
\hline
\end{tabular}

Source: Elaborated by the authors.

\section{ANALYSIS}

Our research objective was to analyze the meaning of work for people with acquired disabilities, emphasizing subjective experiences they have lived by in the professional world. Thus, the transcription content analysis focused on creating categories and subcategories indicative of the relative aspect of the role of work for the interviewees (Boeije, 2010).

During the process of categorization, we separated the categories into two major groups, the first containing aspects that refer to the meaning of work described by the interviewees which find resonance in the literature on the subject. Therefore, these related categories are theoretically referenced (Boeije, 2010). The second category brings together aspects mentioned by interviewees which emerged from the field, that is, they are 
not covered, usually, in the literature on the subject. Besides, the centrality of work is discussed in a transversal manner - since it does not configure meaning in and of itself but indicates the place occupied by work in the lives of these people.

Therefore, the analysis entails three subsections: 1 . The centrality of Work, which emphasizes the importance of work among these other spheres of life for the person with an acquired disability; 2. Traditional Motivational Factors, which emphasizes the role of labor for a disabled person who has found resonance in the literature on meaning in general, while highlighting the pleasure of working and work as a source of social insertion; and 3. Emergent Motivational Factors, which emphasizes the meaning of work categories that are not observed in traditional studies on the subject, but that constitute roles of work associated with a disabled person's identity construction while highlighting stigma resistance and solidary empowerment.

\subsection{Work Centrality}

The subject of the centrality/importance of work appears recurrently in the reports obtained. All interviewees attribute a central role in their lives to their work, which brings meaning and a sense of personal value to their existence.

I feel alive, doing what I enjoy. When I'm on stage, I forget that this or that hurts, I forget that I'm nearly elderly. (E1)

Work is dignity; it gives you autonomy, it dignifies you as a person. (E2)

Work is our usefulness in life, it's what we can do for others, and preferably do well. (E3)

These individuals' involvement with work, beyond just psychological commitment (MOW, 1987), also includes behavioral elements, such as time spent on labor activities:

"My assistant, who works with me says: 'I don't know how you take it." And I answer that I' $1 \mathrm{~m}$ not tired, but if she is, she can go home. (E10)

This situation with electronics forces you to work more, you have access to work all the time, on the computer or phone. You work more than normal. (E6) 
In line with Lima et al., 2013 and Santos and Carvalho-Freitas (2018), work has an important role in the interviewees' lives. However, regarding the decision-making component (MOW, 1987), despite the importance of work, it doesn't appear as the main sphere for the interviewees, since priority seems to be given, in most cases, to the sphere of the family:

I know I need to work, but I also need to live. Work is necessary, but it isn't everything. I think people begin to value life when they live tough situations. (E7)

Family is the priority, for having aided in surpassing limitations. We also have a nice relationship. (E8)

Despite not being the central sphere, the importance of work becomes explicit, especially for the fact that no interviewees seem to have demonstrated any interest in stopping working, except if it is to change activities. This finding resonates with Morse and Weiss' (1955), original observations, in other words, the appreciation for work even when it is not necessary for survival.

Among the greatest fears involving idleness for the interviewed group, there is social isolation, tedium, and depression. These worries denote, as highlighted by Dubar (2005), how established professional relationships and recognition at work participate in identity construction and social creativity, with, consequently, work impediment a reason for personal suffering, loss of self-esteem, and a generator of social disorganization. Similarly to Santos and Carvalho-Freitas' (2018) study, work as a source of occupation appears in the reports, and is essential for the group's well-being. For those interviewed, work is a source of meaning which is sturdily anchored in societal contribution and participation. Usefulness as part of the meaning of work, equally observed by Santos and Carvalho-Freitas (2018), appears highlighted in the interviews:

Quitting work would leave me with serious psychological problems. I'd miss the contact with people, being able to talk, to be with people.

I'd be too idle. I don't have the muscles to do exercise every day; I'd have no activity, I would be depressed. (E10)

When I stop working, I want to have an NGO, to get involved with inclusion education. Pass the knowledge on. (E9) 
In contrast with other groups investigated in the literature on the subject, remuneration did not appear as the main meaning of work. In Lima et al. (2013), and Santos and Carvalho-Freitas (2018) studies, more than a source of income, work was also seen as a mechanism of distancing from the stigma of uselessness, a way of securing independence and evidencing capacity. Even when those interviewed were asked to define the term "work," their reports touched on remuneration as a consequence and necessity, not a goal or an element generator of meaning.

As we live in a capitalist society, it is also what allows our material survival. (E3)

If I didn't have a health plan which allowed for this support, I don't know how things would be. I had to do surgery abroad, and the plan paid for part of it. (E8)

\subsection{Traditional Motivational Factors}

\subsubsection{Work as a source of pleasure and realization}

Most interviewees showed joy in doing their jobs and stated they would still work in a hypothetical situation of extreme richness. The following reports illustrate the priority of work as a source of pleasure and realization comparative to other possible meanings:

Being an actress gives me an actualization. When I'm there, I feel like that's it, sure that I'm in the right place. (E5)

Work for me is love. It wasn't I that chose physiotherapy, but it chose me. (E9)

Work is the exercise of production, of reverting that somehow to your self-management and pleasure. It's a pleasure, isn't it? To me, it's strongly associated with pleasure. (E1)

Such motivation, according to Wrzesniewski et al. (1997), would be of intrinsic origin, as it associates with callings. Pleasure at work appears, in the interviews, as a result of unifying such a mission with potency and talents - relationship also seen in Morin's (2001) studies. In this research, those that demonstrated more pleasure in their work were the ones who 
showed more dedication of time and energy towards it. This finding agrees with what the MOW group's (1987) research shows. This motivational factor finds resonance in Santos and Carvalho-Freitas' (2018) research results, which also identify pleasure and realization as some of the most important meanings of work for those interviewed.

At the same time as the interviewees spoke of the pleasure of working, they also made it a point to state that work is not one's hobby, it requires commitment and, frequently, that people follow through with those commitments despite disliking the work. Intrinsic motivation, even vocational, is not always pleasing (Wrzesniewski et al., 1997):

Music has a subjective quality to it. It's work because I play with pleasure, but not out of pleasure. (E3)

Both the autonomy obtained by way of work, and the recognition that one's job has been well executed and achieved its objective seem to be relevant aspects to a satisfactory job and appear as meanings of work for this group, yet with slightly different connotations. Autonomy appears to be a consequence of work, of financial independence, but also of decision making. For disabled people, work seems to allow a sense of social parity, anchored in capacity and the possibility of guiding one's own professional and personal destiny.

It's not about tying your shoe, but you deciding what shoe to put on. (E1)

To work, you need to surpass obstacles. You need to have autonomy; you don't want to depend on others. That ability to surpass gave me the resourcefulness to achieve that. (E8)

Recognition for the work one has done, for one, appears as work valuation from those who receive the product, and not exactly by superiors or coworkers:

I like having the recognition, of people liking what I do. I feel good because I'm brightening up the lives of many. (E2)

Work is vital; I feel capable of doing things, of helping, of informing and giving people feedback. (E7) 
The origin of meaning from recognition at work differs from the observations of Morin et al. (2007) in their study. For the authors, the value of recognition is linked to their superiors, while, for the disabled interviewees, recognition gives meaning to work but comes from those who receive their service.

\subsubsection{Work as a means of social insertion}

All interviewees reported the importance of social interaction, with clients or colleagues, afforded by work and, especially, the fear of being isolated at home, in case they stop working. In line with the literature studied, for disabled people in the job market, the technical production relationships made viable by work seem to afford strong support towards their inscription in the social structure (Castel, 1998). The following reports illustrate this aspect:

Work is this moment of responsibility with others, with the place where you live. When you're a child you play, you can live in your little world, and when you've grown, you have to work, and you understand that you're part of a whole. (E5)

Feeling like you're part of it also gives you some inclusion, right? You being inserted into society, not just the market. There, you have socialization; you make friends, you've got all this context around it. (E2)

The reports reinforce the role of professional activity, not just as a way of supporting their life, but also as a mechanism of social integration, in which psychological and physical aspects are strongly implied (Dejours, 2004). Likewise, for other workers, contacts and relationships seem to be stimulating, not just for their identity molded by associations, but for the lasting emotional bonds - which trespass the work sphere (Morin, 2001). These social bonds allow one to avoid the feeling of isolation and to find one's places in his/her community.

The importance of work as a means of social insertion was already pointed out by Lima et al. (2013). As highlighted by the authors, the worker's inclusion in the workplace confers a sense of belonging and allows for the creation of relationships which expand into other life spheres. The reports show that work relationships and a positive organizational environment form meaning and are decisive factors when choosing to remain at a job: 
The main reason for choosing it was the environment; it's no use to be earning a large salary in an environment that doesn't do you good, and that ends up causing stress and other consequences. Even more than remuneration. (E2)

The activity itself and the relationship are more important. I would have difficulty working in a place where I was isolated or where I couldn't socialize well with people. (E8)

\subsection{Emerging motivational factors}

The analysis of the content of the reports allowed for the identification of some peculiarities in the meanings of work pointed out by those interviewed. These emerging themes are highlighted here as specific to this group, not being directly aligned with the work attributes and experiences reported in the literature on the subject. Regarding disability acquisition, it has shown to not be a factor of interference in the individuals' professional interests but seemed to provoke subjective life experiences to be lived differently than the ones experienced previous to the disability acquisition.

The fact that those interviewed had acquired their disabilities during their teenage or adult years may explain why meanings associated to the role of work and work motivations were not altered, given that their social and professional identities were already formed during this transition. Based on the reports, it is noticeable that different factors may alter meaning formation, and that a disability is not, necessarily, a causal factor for this to occur.

However, among the categories which confer meaning to work and emerged in the reports with those interviewed are: work as a form of surpassing barriers and combatting stigmas; and work as a path towards empowering one's self and others, mainly because of its social impact. These emerging meanings suggest that work for people with acquired disabilities plays a role that goes beyond the integration made viable by their social insertion. The field observations indicate that work is a way of combatting the stigma of disability, of amplifying the sense of capacity and agency of the disabled person, and takes on, therefore, expanded meanings associated to the reinforcement of their ability, citizenship, and social activism.

\subsubsection{Surpassing barriers and fighting stigmas}

Regarding Castel's (1998) debate on social cohesion, disabled people would be, historically, considered incapable of working (theory of 
disadvantage). The evolution of the terminology utilized to refer to a "disabled person" (Sassaki, 2010) reflects how this group was seen: "invalid," "incapacitated," "defective." The medical model of deficiency reinforces this stigma, as it attributes the problem to the disabled person, leaving that person with the responsibility of adapting to the way in which society presents itself. (Bampi, Guilhem, \& Alves, 2010).

One of those interviewed, who suffers from an autoimmune disease and that, because of this, has been through many surgeries, affirmed that every time he went through surgery, he was asked if he wanted to retire because of invalidity:

I think the doctors suggest that there is not really this vision that work is also important for your mind. If I were a truck driver it might be that I couldn't, but with what I used to do, I could. (E8)

Some interviewees reached the point of considering that a disability would be a wall preventing them from having the jobs they desired and, for that, delayed their plans, but in this day they see this kind of thinking as part of the construction of a stereotype or pattern in the way that activities present in these professions are executed:

I imagine there must've been some resistance from the producers (for being blind), but they (artists) bet on the idea. And everything went well. I was able to beat those obstacles. I played with so many people, went to so many places. (E3)

The obstacles for the inclusion of disabled people, and also their surpassing, according to the social model of disability, are not merely a responsibility the person's with a disability, but also society's, which finds itself leaving them in a disadvantageous situation (Sassaki, 2010). The attitudinal barrier, for example, is associated with stigmas, as a negative predisposition of one person towards another, because of their differences and their conditions assimilated as ideals (Amaral, 1998).

The participant's reports suggest that, by way of a revision of the way they execute the same professional activities they used to do before the acquisition of the disability, or which they dreamed of doing, it was possible to surpass those barriers. In this case, transcending the obstacles to answer their callings and obtain pleasure in work emerged as an additional meaning associated with work, since professional activities allow stigmas to be contested and surpassed on a daily bases: 
Until then I thought of dancing traditionally: the instructor up front doing the movements and the students repeating. Afterward, I did classical ballet, and I'd touch the instructor, her body, understanding the paths I needed to take with my body to reach that place. (E5)

This report shows the rupture of the stereotype or stigma associated with the act of dancing itself, the way it is executed and, also, the stigma that a blind person would not be able to dance, especially professionally. During the interviews, it became evident that some of those interviewed perceived society as disbelieving in their capacity, with work being a way of refuting this stigma and demonstrating power:

Work dilutes the disability because people see that you have the same competency as any other person. (E6)

In sports, it inspired me to say 'I can,' even without a leg. It was like saying: 'Look at that, she has two legs and I still beat her.' (E10)

\subsubsection{Solidarity and empowerment}

Before acquiring the disability, some interviewees saw work only as a means of survival, but, after the acquisition, they saw it as a tool for social transformation and producing value. The experience of disability seems to have brought to the group reflection on their condition and their role in society. Some mention their specific knowledge in the field of medicine, architecture, or law, for example, as tools to care for their peers and society as a whole:

Sometimes, sometimes the person is suffering because of a lack of understanding, we give them a simple orientation, and it changes that person's life. That has no price. (E6)

One of the main criteria in choosing a job seems to be "having a job with a purpose," wanting to "do good"; with this being, frequently, the most significant source of pleasure in work for these people.

Before, there was more the issue of financial necessity. I saw work as a mere source of income, and it is much more than that. That was what changed. Working not only for money, but it's also the satisfaction of doing something greater, something more. (E2) 
At the same time as those interviewed have a profession and a job by way of which they wish to generate impact, many of them also want to exercise that same activity, voluntarily, for people who need their help. In the literature, volunteering is seen as a form of generating value for society (Ferreira, Proença, \& Proença, 2008). Voluntary work does not seem to generate an impact on the well-being of merely the person who receives this work, but especially on the person who offers it (Thoits \& Hewitt, 2001). The necessity of appropriating their new condition and interest in the theme of inclusion and accessibility made it that some interviewees came to dedicate themselves to such a cause. Half of the participants have already participated in courses on inclusion, with the emergence of this interest, in nearly all cases, occurring after the acquisition. Only one of the interviewees had a professional activity associated with inclusion (she was a student of physiotherapy), before the acquisition.

The search for this knowledge was done as a form of social activism, of solidary militancy for those in similar situations. The following reports show how disability made them value the subject so that they searched for knowledge on the subject and professional activity in the field:

Since I am disabled and, in a way, have wandered into the world involved with culture, with art, I started to get involved in accessibility issues. I already knew the audio description, so I started to study more. (E5)

As my limitations increased, I became more attentive towards accessibility in projects (of urban development and transport). (E8)

According to the interviewees, they also attempt to clear up disability issues and act against the formation of stereotypes and prejudiced reactions, not only at work but in all spheres of life.

We shared information, diffused the knowledge. They're people who will be multipliers of a new vision, more realistic about the blind person. (E3)

According to Curado and Menegon (2009), disabled people are part of the universe which volunteers believe needs their help. In this study, those interviewed, in their condition as disabled people, believe they can help others who share similar conditions with them: 
it makes a big difference us being in action for so long (for disabled people), doing things so that these people are seen, noticed differently, more respectable. (E1)

According to Sassaki (2010), empowerment is "the process by which a person, or a group of people, uses their power inherent to their condition to make their choices and decisions, thus assuming control of their lives" (p. 37). Those interviewed have a preoccupation with leaving a legacy, as though the disability they acquired was part of a mission. Even if the activities the person exercised were not directly connected to militancy for inclusion, it is evident that there is, in the demonstration of work capacity itself, an intention to be examples and platforms for that battle.

Showing that paralysis is more internal than external, that we can do it if we want to, that we need to mobilize, that we need to find our space. (E1)

Work for people with acquired disabilities seems to take on a new meaning, for they believe that their professional action consists of an opportunity for them to be examples, while also serving the purpose of inspiring others - notably, people who also have disabilities. The self-empowerment of others was considered an essential aspect of work, reflecting itself in different forms of social work.

\section{FINAL CONSIDERATIONS}

This study's objective was to investigate the meaning of work for people with acquired disabilities present in the job market. There were ten individuals interviewed, they had acquired disabilities in their teenage years or adulthood, because of accidents or degenerative diseases. Based on the analysis of the interviews, we observed that, in this group, work appears plural, with multiple meanings, not just comparatively among those interviewed, but also for each. Work plays a central role in the participants' lives, who, in turn, feel highly committed to it. Not working is seen as a source of unrest, because of the tedium and isolation, with, therefore, a source of suffering to those interviewed. In this way, the study reinforces Dejours (2004) in that work is, for constituting a mechanism of insertion into the societal structure, a factor of integration and reinforces these 
people's identities. It is worth noting, however, that despite this centrality, people who have acquired some disability seem more sensitive to the necessity of balance between work and family.

In consonance with other studies on the subject (Lima et al., 2013; Santos \& Carvalho-Freitas, 2018), for people with acquired disabilities work mainly represents a source of pleasure and representation, as well as social insertion. Also, we observed other meanings attributed to work by this group, which do not traditionally appear in studies on the subject, such as empowerment of one's self and others, combat against stigmas, and the surpassing of barriers for the exercise of work activities.

Relating to findings by recent national studies on the meaning of work and disabled people, such as Lima et al. (2013) study, and Santos and Carvalho-Freitas' (2018) study, there was the appearance in our research of the importance of breaking incapacity and social interaction myths. Furthermore, there were no complaints about conceited treatment in the reports, neither by family nor colleagues. Pity, fear, and overprotection, indicated in studies such as Paiva et al. (2015), did not appear in the interviewees' reports, neither did meaningless activities, as reported the interviewed from Coelho, Sampaio, and Mancini (2014).

In this way, it is important to note that the group analyzed may be considered privileged within the universe of disabled people, as their members seem to have jobs rich in meaning besides being inserted in the job market. This difference allows the perception of factors in the context of these interviewees work that make their jobs "rich," and what attracts them, even if they don't need that job to survive.

As an original contribution, we found new meanings of work for people with acquired disabilities in this study. Reports suggest that these people found in work, not only the opportunity to surpass their conditions' challenges but also to resist stigmas related to disability. Furthermore, they see meaning in work that transcends themselves, which allow them to serve purposes associated with solidarity and empowerment of one's self and others. Thus, this study presents a different image of the worker with an acquired disability, which points to distinctive characteristics, and allows a better comprehension of who this person is; in this case, an individual who sees him/herself as powerful instead of incapable, and to who the meaning of work also has the possibility of being a tool for social transformation.

The acquisition of disabilities does not seem to have directly influenced the interviewees' work motivations, or their chosen careers. However, the reports evidenced a necessity that these individuals develop new resources to continue to meet their vocations and give them pleasure at work. 
Furthermore, our findings indicate that having the experience of overcoming such challenges and the social impact earned from work also seems to have a positive impact on the disabled person's identity construction, contributing to strengthening their self-concept.

In future research, we recommend the continuation of roles and expectations towards work and disabled people, as well as their experiences in the work environment. New studies may compare meanings of work for people with acquired and congenital disabilities, and among people with acquired disabilities with different work relations and with different occupations. Furthermore, future studies may focus on the influence of demographic elements, such as income, age, or region of residence, in the construction of the meaning of work for disabled people, as well as on the role of other individual differences between the members of this group.

Another possibility for future studies is to focus on the difference between the meanings of work for distinct types of disabled people, more specifically physically, sensorially, and intellectually disabled people. Comparing people with different disabilities allows for the analysis of independence and autonomy aspects based on the particularities of the disabilities, especially, the social view of them. Also, future studies may investigate interfaces between the meaning of work and the experience of barriers and discrimination at work for the disabled person. In particular, studies should emphasize the interactions between the meaning of work and life experiences of greater or lesser inclusion, as antecedents of job satisfaction, of well-being and quality of life at work, and of disabled workers' attitudes towards their employers.

\section{REVISITANDO O TRADICIONAL: O SENTIDO DO TRABALHO PARA PESSOAS COM DEFICIÊNCIA ADQUIRIDA}

\section{RESUMO}

Objetivo: O estudo teve como objetivo investigar os sentidos atribuídos ao trabalho por pessoas com deficiência adquirida.

Originalidade/valor: As pesquisas nacionais sobre o tema pouco têm focado no entendimento do sentido do trabalho para trabalhadores com deficiência. 
Design/metodologia/abordagem: Foram realizadas entrevistas em profundidade com dez pessoas que adquiriram uma deficiência e estão atualmente inseridas no mercado de trabalho.

Findings: A análise sugeriu que, para o grupo entrevistado, o trabalho compartilha sua importância com outras esferas da vida, como as afetivas e familiares. Além dos sentidos tradicionalmente discutidos na literatura sobre o tema, tais como o prazer em trabalhar e o trabalho como forma de interação social, há novos sentidos atribuídos ao trabalho por este grupo, associados à identidade da pessoa com deficiência, como a superação de barreiras, o combate ao estigma da incapacidade e a geração de impacto positivo na sociedade. Por outro lado, a remuneração e a progressão na carreira apareceram como consequências e não como fatores de geração de sentido. As descobertas desse estudo ajudaram a compreender melhor os diferentes sentidos atribuídos ao trabalho por pessoas com deficiência adquirida. Ademais, seus achados indicaram a existência de "outros" sentidos, além daqueles usualmente abordados na literatura sobre o tema, o que reforça a contribuição desse artigo para o campo de estudos sobre sentido do trabalho.

\section{$\int$ PALAVRAS-CHAVE}

Sentido do trabalho. Pessoa com deficiência. Inclusão. Diversidade. Mercado de Trabalho.

\section{$\int$ REFERENCES}

Assunção, R. V., Carvalho-Freitas, M. N. D., \& Oliveira, M. S. D. (2015). Satisfação no trabalho e oportunidades de desenvolvimento da carreira entre profissionais com deficiência. Revista Psicologia Organizações e Trabalho, 15(4), 340-351. doi:10.17652/rpot/2015.4.556

Amaral, L. A. (1998). Sobre crocodilos e avestruzes: Falando de diferenças físicas, preconceitos e sua superação. In J. G. Aquino (Eds.). Diferenças e preconceitos na escola: alternativas teóricas e práticas. São Paulo, SP: Summus Editorial.

Ashforth, B. (2000). Role transitions in organizational life: An identity-based perspective. New York, NY: Routledge. 
Barnes, C., \& Mercer, G. (2005). Disability, work, and welfare: Challenging the social exclusion of disabled people. Work, employment and society, 19(3), 527-545. doi:10.1177\%/0950017005055669

Bendassolli, P., \& Gondim, S. M. G. (2014). Significados, sentidos y función psicológica del trabajo: Discusión de esta tríada conceptual y sus desafíos metodológicos. Avances en Psicología Latinoamericana, 32(1), 131-147. doi:10.12804/apl32.1.2014.09

Boeije, H. (2010). Analysis in qualitative research. London, UK: Sage.

Bogart, K. R. (2014). The role of disability self-concept in adaptation to congenital or acquired disability. Rehabilitation Psychology, 59(1), 107-115. doi:10.1037/a0035800

Brasil (1991a). Decreto 129. Promulga a Convenção no. 159 da Organização Internacional do Trabalho (OIT) sobre Reabilitação Profissional e Emprego de Pessoas Deficientes. Brasília, DF: DOU.

Brasil (1990). Lei no. 8,112, de 11 de dezembro de 1990.

Brasil (1991b). Lei no. 8,213, de 24 de julho de 1991b.

Bampi, L. N. S., Guilhem D., \& Alves E. D. (2010). Social model: A new approach of the disability. Revista Latino-Americana de Enfermagem, 18(4), 816-23. doi:10.1590/S0104-11692010000400022

Brief, A. P., \& Nord, W. R. (Eds.). (1990). Meanings of occupational work: A collection of essays. Minneapolis, MN: Lexington Books.

Castel, R. (1998). As metamorfoses da questão social: uma crônica do salário. Petrópolis, RJ: Vozes.

Cavazotte, F. C. N., Lemos, A. H., \& Brollo, M. (2014). Trabalhando melhor ou trabalhando mais? Um estudo sobre usuários de smart phones corporativos. Organizações \& Sociedade, 21 (68). doi:10.1590/S1984-92302014000 100002

Coelho, C. M., Sampaio, R. F., \& Mancini, M. C. (2014). Trabalhadores com deficiência: Vivências de prazer e sofrimento. Psicologia \& Sociedade, 26(1), 214-223. doi:10.1590/S0102-71822014000100023

Curado, J. C., \& Menegon, V. S. M. (2009). Gênero e os sentidos do trabalho social. Psicologia \& Sociedade, 21 (3), 431-431.

Dejours, C. (2004). Subjetividade, trabalho e ação. Revista Produção, 14(3), 27-34. doi:10.1590/S0103-65132004000300004

Dubar, C. (2005). A socialização: construção das identidades sociais e profissionais. São Paulo: Martins Fontes. 
Durkheim, É. (1977). Da divisão do trabalho social. São Paulo, SP: Martins Fontes.

Ferreira, M., Proença, T., \& Proença, J. F. (2008). As motivações no trabalho voluntário. Revista Portuguesa e Brasileira de Gestão, 7(3), 43-53.

Glaser, B.G. \& Strauss, A.L. (2006). The discovery of grounded theory: Strategies for qualitative research. New York, NY: Aldine de Gruyter.

Hackman, J. R., \& Oldham, G. R. (1976). Motivation through the design of work: Test of a theory. Organizational Behavior and Human Performance, 16(2), 250-279. doi:10.1016/0030-5073(76)90016-7

Johansson, U., \& Tham, K. (2006). The meaning of work after acquired brain injury. American Journal of Occupational Therapy, 60(1), 60-69. doi:10. 5014/ajot.60.1.60

Leiulfsrud, A. S., Ruoranen, K, Ostermann, A., \& Reinhardt, J. D. (2016). The meaning of employment from the perspective of persons with spinal cord injuries in six European countries. Work, 55(1), 133-144. doi:10.3233/ WOR-162381

Lima, M. P., Tavares, N. V., Brito, M. J., \& Cappelle, M. C. A. (2013). O sentido do trabalho para pessoas com deficiência. Revista de Administração Mackenzie, 14(2), 42-68. doi:10.1590/S1678-69712013000200003

Maccali, N., Kuabara, P. S. S., Takahashi, A. R. W, Roglio, K. D., \& Boehs, S. T. M. (2015). As práticas de recursos humanos para a gestão da diversidade: a inclusão de deficientes intelectuais em uma federação pública do Brasil. Revista de Administração Mackenzie, 16(2), 157-187. doi:10.1590/16 78-69712015/administracao.v16n2p157-187

Maia, A. M. C., \& Freitas, M. N. C. (2015). O trabalhador com deficiência na organização: um estudo sobre o treinamento e desenvolvimento e a adequação das condições de trabalho. Revista Eletrônica de Administração, 21 (3), 689-718. doi:10.1590/1413-2311.0722014.54834

Moreno, J. C. (2009). Conceito de minorias e discriminação. Direito e Humanidades, (17). 141-156.

Morin, E. M. (2001). Os sentidos do trabalho. Revista de administração de empresas, 41 (3), 8-19. doi:10.1590/S0034-75902001000300002

Morin, E., Tonelli, M. J., \& Vieira Pliopas, A. L. (2007). O trabalho e seus sentidos. Psicologia \& Sociedade, 19(1), 47-56. doi:10.1590/S010271822007000400008

Morse, N. C., \& Weiss, R. S. (1955). The function and meaning of work and the job. American Sociological Review, 20(2), 191-198. doi:10.2307/2088325 
MOW (1987). The meaning of working. doi:10.1002/job.4030100109 Ministério do Trabalho e Emprego [MTE] (2015). Informações Sociais, RAIS-Relação Anual. Brasília, DF: Ministério do Trabalho e Emprego.

Offe, C. (1989) Capitalismo desorganizado. São Paulo, SP: Brasiliense.

Paiva, J. C. M., Bendassolli, P. F., \& Torres, C. C. (2015). Sentidos e significados do trabalho: dos impedimentos às possibilidades do trabalho de pessoas com deficiências. Estudos e Pesquisas em Psicologia, 15(1), 218-239.

Randolph, D. S. (2005). The meaning of workplace discrimination for women with disabilities. Work, 24(4), 369-380.

Rodrigues, A. L., Barrichello, A., \& Morin, E. M. (2016). Os sentidos do trabalho para profissionais de enfermagem: Um estudo multimétodos. Revista de Administração de Empresas, 56(2), 192-208. doi:10.1590/S0034759020160206

Rosso, B. D., Dekas, K. H., \& Wrzesniewski, A. (2010). On the meaning of work: A theoretical integration and review. Research in Organizational Behavior, 30, 91-127. doi:10.1016/j.riob.2010.09.001

Ruoranen, K., Post, M. W., Juvalta, S., \& Reinhardt, J. D. (2015). Participation and integration from the perspective of persons with spinal cord injury from five European countries. Journal of Rehabilitation Medicine, 47(3), 216222. doi:10.2340/16501977-1911

Santos, J. C., \& Carvalho-Freitas, M. (2018). Sentidos do trabalho para pessoas com deficiência adquirida. Psicologia E Sociedade, 30, e160054. doi:10.1590/1807-0310/2018v30160054

Sassaki, R. K. (2010). Inclusão: Construindo uma sociedade para todos. Rio de Janeiro, RJ: WVA.

Sassaki, R. K. (2009). Inclusão: Acessibilidade no lazer, trabalho e educação. Revista Nacional de Reabilitação, Mar./Apr, year XII, 10-16. Retrieved from https://acessibilidade.ufg.br/up/211/o/SASSAKI_-_Acessibilidade. pdf? 1473203319

Sá, M. A. D., Oliveira, M. I. M., Dias, S. M. R. C., \& Barbosa, M. D. L. A. (2017). Human Resources practices and inclusion of people with disabilities in the hotel industry of Belém, Brazil: A multiple case study. Revista de Gestão, 24(1), 13-23. doi:10.1016/j.rege.2016.08.002

Spinelli-de-Sá, J. G., \& Lemos, A. H. D. C. (2017). Sentido do trabalho: Análise da produção científica brasileira. Revista do Mestrado em Administração e Desenvolvimento Empresarial, 21 (3), 21-39. doi:10.21714/2237-51392017 v21n3p021039 
Thoits, P. A., \& Hewitt, L. N. (2001). Volunteer work and well-being. Journal of Health and Social Behavior, 42 (2), 115-131doi:10.2307/3090173

Tolfo, S. D. R., Coutinho, M. C., Almeida, A. D., Baasch, D., \& Cugnier, J. S. (2005). Revisitando abordagens sobre sentidos e significados do trabalho. Anais do Fórum CRITEOS, Brazil, Porto Alegre, RS.

Tolfo, S. D. R., \& Piccinini, V. C. (2007). Sentidos e significados do trabalho: Explorando conceitos, variáveis e estudos empíricos brasileiros. Psicologia E Sociedade, 19(1), 38-46. doi:10.1590/S0102-71822007000400007

Wrzesniewski, A., McCauley, C., Rozin, P., \& Schwartz, B. (1997). Jobs, careers, and callings: People's relations to their work. Journal of Research in Personality, 31 (1), 21-33. doi:10.1006/jrpe.1997.2162

Ullah, M.M., Fossey, E., Stuckey, R. (2017). The meaning of work after spinal cord injury: A scoping review. Spinal Cord, 56, 92-105. https://doi. org/10.1038/s41393-017-0006-6

\section{AUTHOR NOTES}

Mariana F. G. Galvão, IAG Business School, Pontifical Catholic University of Rio de Janeiro (PUC-Rio); Ana Heloisa da C. Lemos, Instituto Universitário de Pesquisas do Rio de Janeiro (IUPERJ), Universidade Cândido Mendes (UCAM); \& Flávia de S. C. N. Cavazotte, School of Business, Virginia Commonwealth University.

Mariana F. G. Galvão is now Project Manager at Fundo Brasileiro pela Biodiversidade (FUNBIO); Ana Heloisa da C. Lemos is now Professor of Administration at Pontifical Catholic University of Rio de Janeiro (PUC-Rio); \& Flávia de S. C. N. Cavazotte, Professor of Administration at Pontifical Catholic University of Rio de Janeiro (PUC-Rio).

Correspondence concerning this article should be addressed to Ana Heloisa da C. Lemos, Marques de São Vicente Street, 225, Gavea, Rio de Janeiro, Rio de Janeiro, Brazil, CEP: 22451-900.

E-mail: aheloisa@iag.puc-rio.br

\section{EDITORIAL BOARD}

Editor-in-chief

Silvio Popadiuk

Associated Editor

Andrea Rodrigues

(iD) https://orcid.org/0000-0002-8750-4679

Technical Support

Vitória Batista Santos Silva
EDITORIAL PRODUCTION

Publishing Coordination

Irina Migliari

Language Editor

Daniel Leão

Editorial Trainee

Maria Luiza Vanz

Layout Designer

Emap

Copyeditor

Irina Migliari

Graphic Designer

Libro 